Original Article

\title{
METHOD DEVELOPMENT ON ANALYSIS CYCLOPHOSPHAMIDE AND 4- HYDROXYCYCLOPHOPHAMIDE IN DRIED BLOOD SPOT AND ITS APPLICATION IN BREAST CANCER PATIENTS
}

\author{
YAHDIANA HARAHAP ${ }^{1}$, NURLITA GUSTIYANTII ${ }^{1}$, AYU EGAHMUSTIKA SUNANTO ${ }^{1}$, HARMITA ${ }^{1}$, DENNIJOKO \\ PURWANTO $^{2}$
}

1Bioavailability and Bioequivalence Laboratory, Faculty of Pharmacy, Universitas Indonesia, ${ }^{2}$ Medical Functional Staff Surgical Oncology, "Dharmais" Cancer Hospital, Jakarta, Indonesia

Email: yahdiana03@yahoo.com

Received: 15 Oct 2019, Revised and Accepted: 28 Apr 2020

ABSTRACT

Objective: To develop the method for the simultaneous analysis of cyclophosphamide and 4-hydroxycyclophosphamide (4-OHCP) in Dried Blood Spot (DBS) using Ultra-High-Performance Liquid Chromatography-Tandem Mass Spectrometry (UPLC-MS/MS) and its application in breast cancer patients for therapeutic drug monitoring.

Methods: Sample preparation used protein precipitation with methanol and acetonitrile $(2: 1 \mathrm{v} / \mathrm{v})$. The separation was conducted using $1.7 \mu \mathrm{m}(2.1$ x $100 \mathrm{~mm}$ ) Waters Acquity ${ }^{\mathrm{TM}}$ UPLC C18 column; mobile phase consists of $0.01 \%$ formic acid and methanol (50:50 v/v) with isocratic elution, column temperature $30^{\circ} \mathrm{C}$, flow rate $0.3 \mathrm{ml} / \mathrm{min}$ and hexamethylphosphoramide (HMP) used as an internal standard. Analysis was performed by a triple quadrupole mass spectrometry with a positive ion mode of Electrospray Ionization. Cyclophosphamide was detected at $\mathrm{m} / \mathrm{z} 260.968>139.978$, 4$\mathrm{OHCP}$ at $\mathrm{m} / \mathrm{z} 338.011>224.979$, and HMP at $\mathrm{m} / \mathrm{z}$ 180.17>92.08. The method was applied to quantify cyclophosphamide and 4-OHCP in DBS of breast cancer patients. Blood samples were collected at 2 and $4 \mathrm{~h}$ after cyclophosphamide administration for therapeutic drug monitoring.

Results: The method was linear in the range of $50-30.000 \mathrm{ng} / \mathrm{ml}$ for cyclophosphamide and $10-1000 \mathrm{ng} / \mathrm{ml}$ for $4-\mathrm{OHCP}$. Lower Limit of Quantification (LLOQ) concentration of cyclophosphamide was $50 \mathrm{ng} / \mathrm{ml}$ and 4-OHCP was $10 \mathrm{ng} / \mathrm{ml}$. Accuracy and precision within-run and between-run met the requirements with $\%$ diff and CV, not exceeding $\pm 15 \%$ and not more than $\pm 20 \%$ for LLOQ concentration. The results from DBS samples of cancer patients showed that the level of cyclophosphamide was in the range of $6045.980 \mathrm{ng} / \mathrm{ml}$ to $37024.403 \mathrm{ng} / \mathrm{ml} \mathrm{and} 4-\mathrm{OHCP}$ was in the range $33.155 \mathrm{ng} / \mathrm{ml}$ to $246.362 \mathrm{ng} / \mathrm{ml}$.

Conclusion: The developed method met the requirements of all validation parameters under the Guideline on Bioanalytical Method Validation by the European Medicines Agency in 2011. Method can be applied on DBS of cancer patients and the results showed that cyclophosphamide and 4-OHCP was detected on 17 samples of breast cancer patients. This can be one of the parameters for therapeutic drug monitoring.

Keywords: Cyclophosphamide, 4-OHCP, UPLC-MS/MS, DBS, Cancer

(C) 2020 The Authors. Published by Innovare Academic Sciences Pvt Ltd. This is an open access article under the CC BY license (http://creativecommons.org/licenses/by/4.0/) DOI: http://dx.doi.org/10.22159/ijap.2020v12i4.36092. Journal homepage: https://innovareacademics.in/journals/index.php/ijap

\section{INTRODUCTION}

Cyclophosphamide is an anticancer drug that acts as an alkylating agent and is used singly, as well as being a regimen in multiple types of cancer therapies such as non-Hodgkin's lymphoma, sarcoma, and breast cancer [1]. Cyclophosphamide is a prodrug that requires activation by the cytochrome P450 enzyme to convert into its active metabolite, 4-OHCP. This metabolite is in balance with its tautomeric form, aldophosphamide, which will become its active form, phosphoramide mustard and acrolein [2]. The number of enzymes that play a role in the metabolism of cyclophosphamide can cause various expressions and activities among patients, thus contributing to the metabolism, efficacy and toxicity of this drug [3]. Therefore, a method that can monitor the pharmacokinetic parameters of cyclophosphamide is needed to determine the relationship between drug dosage and its efficacy.

Quantitative analytical methods of cyclophosphamide and 4-OHCP have been described previously using High-Performance Liquid Chromatography (HPLC) [4] and Liquid Chromatography-Tandem Mass Spectrometry (LC-MS/MS) [5-7]. However, quantitative analytical methods of cyclophosphamide and 4-OHCP in DBS simultaneously using UPLC-MS/MS have never been done before. UPLC is a technical advancement of liquid chromatography where there are innovations in instrumentation and particle size to improve the resolution, speed, and sensitivity of the method [8].

4-OHCP metabolites are unstable in biological fluids such as in plasma, which has a half-life of 6 min [7]; this can be overcome by performing derivatization procedures prior to analysis $[7,9,10]$. In this study, an optimization and validation method for the analysis of cyclophosphamide and 4-OHCP in DBS was carried out using UPLCMS/MS. Validation parameters are tested according to the requirements of the Guidelines on Bioanalytical Method Validation by the European Medicines Agency in 2011.

Cancer patients who receive cytostatic therapy are the priority of therapeutic drug monitoring to ensure that patients receive safe, effective and rational drugs, so it will minimize drug-related problems and optimize therapeutic effects [11]. After obtaining an optimal and valid method, the method was applied by analyzing dried blood spot samples of breast cancer patients in "Dharmais" Cancer Hospital as one of the effort for therapeutic drug monitoring. DBS samples were analyzed at $\mathrm{C}_{\max }$ and elimination phase.

\section{MATERIALS AND METHODS}

\section{Equipment}

Ultra high-performance liquid chromatography (Waters Xevo TQD Triple Quadrupole) consisting of Quartenary Solvent Manager (Acquity UPLC H-Class), Sample Manager (Acquity UPLC), Nitrogen generator compressor (PEAK Scientific), UPLC Acquity column BEH C18 $(100 \mathrm{~mm} \times 2.1 \mathrm{~mm}) 1.7 \mu \mathrm{m}$, a triple quadrupole (Xevo TQD) mass analyzer with an ionization source (ZsprayTM)

\section{Materials}

Cyclophosphamide (Sigma Aldrich);4-OHCP-d4 Kit (Santa Cruz Biotechnology); HMP (Sigma Aldrich); semicarbazide hydrochloride (Sigma Aldrich); methanol, acetonitrile and formic acid, were 
purchased from Merck Indonesia; aqua dest; and blood (Indonesian Red Cross).

Method was applied on dried blood spot samples of 17 breast cancer patients who received cyclophosphamide. Patients received 700$1114 \mathrm{mg} / \mathrm{m}^{2}$ doses of cyclophosphamide. Blood samples were collected at $2 \mathrm{~h}$ and $4 \mathrm{~h}$ after administration.

The inclusion criteria of patients such as:

a. Patient of Dharmais Cancer Hospital.

b. Receive cyclophosphamide as their chemotherapy regiment

c. Patients age is 18-65 y old during the blood collection

The exclusion criteria of patients such as:

a. Patients is not willing to take part in the research and not signing the informed consent.

\section{Stock solution}

A $10 \mathrm{mg}$ cyclophosphamide was dissolved in methanol until a concentration of $1 \mathrm{mg} / \mathrm{ml}$ cyclophosphamide was obtained. A $2.5 \mathrm{mg}$ 4-OHCP was dissolved with methanol until a concentration of 0.25 $\mathrm{mg} / \mathrm{ml} 4-\mathrm{OHCP}$ was obtained. A $10 \mathrm{mg} \mathrm{HMP}$ as internal standard was dissolved with methanol until a concentration of $1 \mathrm{mg} / \mathrm{ml} \mathrm{HMP}$ was obtained.

\section{Liquid chromatography-mass spectrometry instrument and condition}

The UPLC-MS/MS system consisted of a binary pump, autosampler, C18 Acquity BEH column $(1.7 \mu \mathrm{m}, 100 \mathrm{mn} .1 \mathrm{~mm}$, Waters,

Milford, MA, USA) using Van Guard TM BEH $1.7 \mu \mathrm{m}$ precolumn, and mass spectrometry type quadrupole (Xevo TQD, Waters). The separation was performed using a mobile phase of $0.01 \%$ formic acid in water-methanol $(50: 50, \mathrm{v} / \mathrm{v})$ with isocratic elution mode at $0.3 \mathrm{ml} / \mathrm{min}$ for $4 \mathrm{~min}$, column temperature of $30{ }^{\circ} \mathrm{C}$, and an ionization method of ESI+. The quantitation was conducted using multiple reaction monitoring (MRM) and the quantitation traces were $260.968>139.976$ for cyclophosphamide, $338.011>224.979$ for 4-OHCP-semicarbazide (4-OHCP-SCZ), and 180.17>92.08 for HMP. The injection volume was $10 \mu \mathrm{l}$.

\section{Derivatization solution}

Semicarbazide hydrochloride standard was dissolved with $10 \mathrm{ml}$ of 50 mmol potassium phosphate $(\mathrm{pH}$ 7.4) buffer until 2 M concentration was acquired.

\section{Optimization of derivatization procedure}

The derivatization procedure is done by applying $2 \mathrm{M}$ semicarbazide hydrochloride on DBS paper, then dried for $2 \mathrm{~h}$ prior to blood spotting. Furthermore, the blood containing the analyte was applied on paper and sample preparation was carried out. The volume of derivative solution tested was $10 \mu \mathrm{l}, 20 \mu \mathrm{l}, 30 \mu \mathrm{l}, 40 \mu \mathrm{l}$, and $50 \mu \mathrm{l}$.

\section{Optimization of sample preparation}

Optimization of sample preparation began with the selection of extraction methods between protein precipitation with methanol, liquid-liquid extraction with ethyl acetate-acetonitrile, and protein precipitation followed by liquid-liquid extraction. The next step is optimization of selected extraction methods. First, blood spotting volume was optimized for $10 \mu \mathrm{l} ; 20 \mu \mathrm{l}$; and $30 \mu \mathrm{l}$, then the DBS paper was left to dry at room temperature and was optimized for 1; 2; and $3 \mathrm{~h}$. Blood spots were cut and put into $1.5 \mathrm{ml}$ microtube, then $20 \mu \mathrm{l}$ HMP $1 \mu \mathrm{g} / \mathrm{ml}$ solution as the internal standard was added to the microtube and vortex mixed for $20 \mathrm{~s}$. After that, the mixture was extracted with methanol and acetonitrile with the following combination: $1: 0 \mathrm{v} / \mathrm{v} ; 1: 1 \mathrm{v} / \mathrm{v} ; 1: 2 \mathrm{v} / \mathrm{v} ; 2: 1 \mathrm{v} / \mathrm{v}$; and $0: 1 \mathrm{v} / \mathrm{v}$ and the volume was optimized for $200 \mu \mathrm{l} ; 500 \mu \mathrm{l} ; 800 \mu \mathrm{l}$; and $1000 \mu \mathrm{l}$. The mixture was vortex mixed, and was optimized for $4 ; 5$; and $6 \mathrm{~min}$, sonication was optimized for 5 ; 10; and $15 \mathrm{~min}$, and centrifugation optimization was performed for $10 \mathrm{~min}$ at $5223.296 \mathrm{~g} ; 8161.4 \mathrm{~g}$; and $11752.416 \mathrm{~g}$. A total of $900 \mu \mathrm{l}$ of supernatants were evaporated at 60
${ }^{\circ} \mathrm{C}$ for 20 min under $\mathrm{N}_{2}$ gas flow. The residue was reconstituted with $100 \mu \mathrm{l}$ of mobile phase $(0,01 \%$ formic acid in water-methanol = $50: 50 \mathrm{v} / \mathrm{v}$ ), vortex mixed for $20 \mathrm{~s}$, and centrifuged for $5 \mathrm{~min}$ at $1147.068 \mathrm{~g}$. Finally $10 \mu \mathrm{l}$ of aliquot was injected into the chromatography system.

\section{Method validation}

The full validation of cyclophosphamide and 4-OHCP analysis method in DBS with parameters such as selectivity, carry over, LLOQ, linearity of calibration curve, accuracy and precision, recovery, dilution integrity, matrix effect, and stability [12].

This study was approved by the Ethics Committee of "Dharmais" Cancer Hospital (No.037/KEPK/III/2018).

\section{Application of the method-sampling procedure}

"Dharmais" Cancer Hospital patients was selected as the subject of the study according to the inclusion and exclusion criteria. Patients were given explanations related to the research and if the patients willing to be the subject, patients would sign an informed consent. Blood samples were taken by finger prick method at 2 and $4 \mathrm{~h}$ after cyclophosphamide regiment chemotherapy was given to the patients.

\section{RESULTS}

\section{Optimization of derivatization procedure}

The optimum derivatization procedure was done by applying $20 \mu \mathrm{l}$ of semicarbazide hydrochloride $2 \mathrm{M}$ on DBS paper, then dried for $2 \mathrm{~h}$ prior to blood spotting. Furthermore, the blood containing the analyte was applied on paper and sample preparation was carried out.

\section{Optimization of sample preparation}

The optimum sample preparation was obtained by protein precipitation. Blood containing analytes was spotted $30 \mu \mathrm{l}$ on DBS paper and left to dry at room temperature for $3 \mathrm{~h}$. Blood spots were cut and put into $1.5 \mathrm{ml}$ microtube, then $20 \mu \mathrm{l} \mathrm{HMP} 1 \mu \mathrm{g} / \mathrm{ml}$ solution as the internal standard was added to the microtube and vortex mixed for $20 \mathrm{~s}$. After that, the mixture was extracted with $1000 \mu \mathrm{l}$ methanol-acetonitrile $=2: 1 \mathrm{v} / \mathrm{v}$. The mixture was vortex mixed for 4 min, sonication for $15 \mathrm{~min}$, and centrifugation was performed for 10 min at $11752.416 \mathrm{~g}$. A total of $900 \mu \mathrm{l}$ of supernatants were evaporated at $60^{\circ} \mathrm{C}$ for 20 min under $\mathrm{N}_{2}$ gas flow. The residue was reconstituted with $100 \mu \mathrm{l}$ of the mobile phase, vortex mixed for $20 \mathrm{~s}$, and centrifuged for $5 \mathrm{~min}$ at 1147.068g. Afterward, $10 \mu \mathrm{l}$ of aliquot was injected into the chromatography system.

\section{Method validation}

\section{a. LLOQ and calibration curve}

The LLOQ of cyclophosphamide was $50 \mathrm{ng} / \mathrm{ml}$ with $\mathrm{CV}$ of $4.42 \%$ and \%diff between $7.16 \%$ to $19.62 \%$ and $4-\mathrm{OHCP}$ was $10 \mathrm{ng} / \mathrm{ml}$ with $\mathrm{CV}$ of $6.43 \%$ and \%diff between- $18.27 \%$ to- $6.76 \%$. The calibration curve was linear in the concentration range of $50-30000 \mathrm{ng} / \mathrm{ml}$ for cyclophosphamide with correlation coefficient $(r)>0.9972$ and $10-$ $1000 \mathrm{ng} / \mathrm{ml}$ for 4-OHCP with correlation coefficient (r) $>0.9983$. Calibration curve was calculated with a weighted linear curve fit equation $1 / x$ [13].

\section{b. Selectivity}

The selectivity was performed on LLOQ concentrations and blanks using six different blood sources. The results show that the interference or impurity on the retention time of analytes and internal standard is still meet the criteria $<20 \%$ of LLOQ concentration and $<5 \%$ for the internal standard according to European Medicines Agency guideline of bioanalytical method validation. The chromatogram of the blank sample can be seen in fig. 1. The chromatogram of cyclophosphamide, 4-OHCP-SCZ, and HMP with four-level concentrations which was LLOQ, Quality Control Low (QCL), Quality Control Medium (QCM), Quality Control High (QCH) can be seen in fig. 2 . 


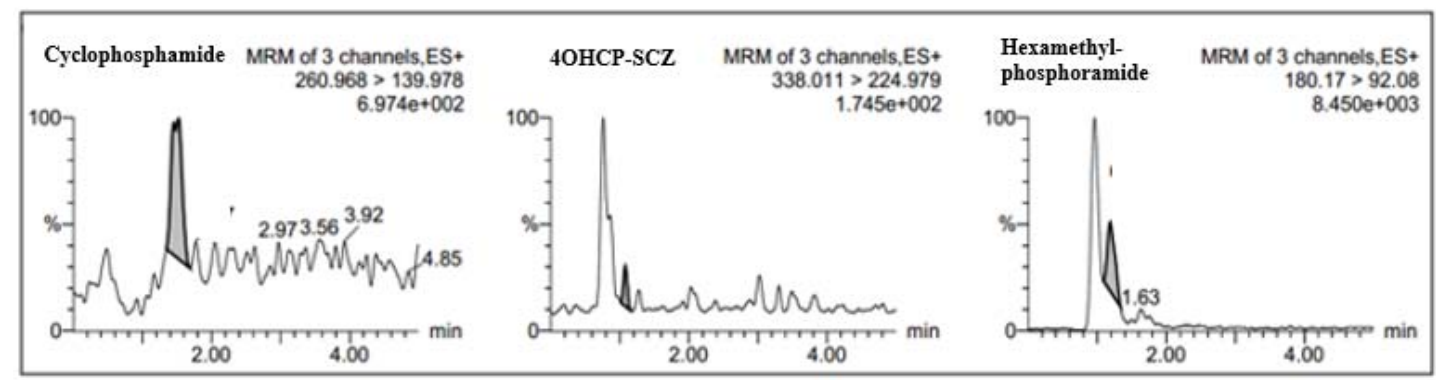

Fig. 1: The chromatogram of blank sample

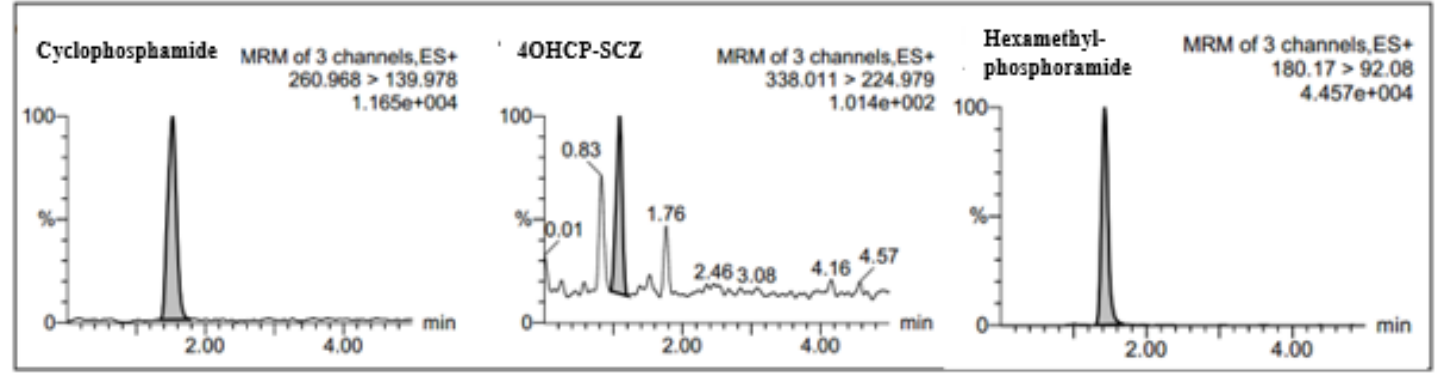

(a) LLOQ

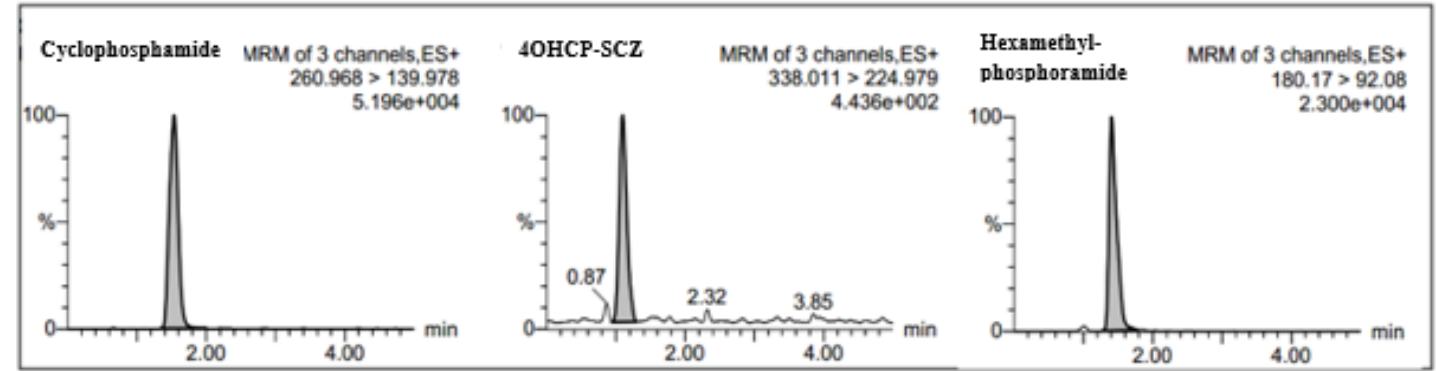

(b) QCL

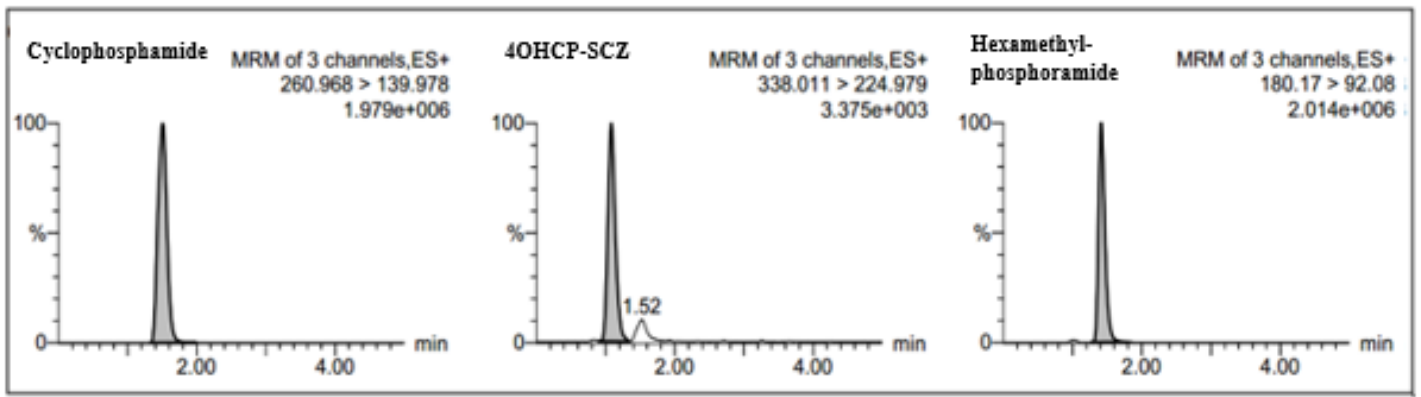

(C) QCM

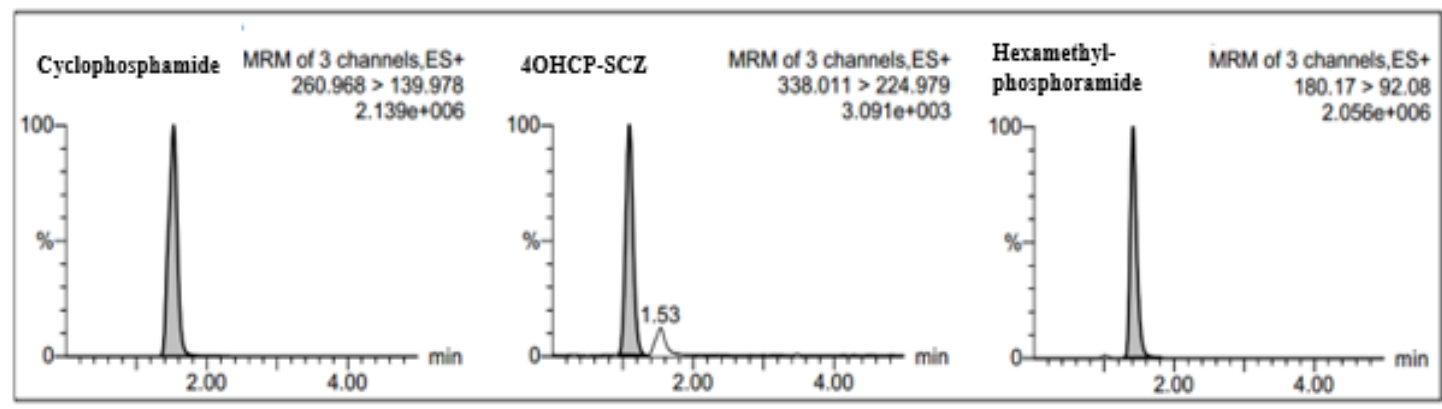

(d) $\mathrm{QCH}$

Fig. 2: The chromatogram of LLOQ, QCL, QCM, QCH, and ULOQ concentration 
Table 1: Data of carry over

\begin{tabular}{llll}
\hline Blank sample & Cyclophosphamide carry over (\%) & 4-0HCP carry over (\%) & Internal standard carry over (\%) \\
\hline Blank 1 & 9.75 & 2.33 & 4.37 \\
Blank 2 & 8.11 & 1.22 & 3.31 \\
Blank 3 & 8.84 & 4.84 & 2.01 \\
Blank 4 & 7.16 & 4.61 & 3.19 \\
Blank 5 & 10.11 & 1.62 & 3.73 \\
Average & 8.80 & 2.92 & 3.32 \\
\hline
\end{tabular}

\section{c. Carry over}

The result shows no carry over in blank sample after injection of the highest concentration (ULOQ) sample. The carry over percentage still meets the requirements for analytes $<20 \%$ and $<5 \%$ for the internal standard. The result can be seen in table 1 .

\section{d. Accuracy, precision, and recovery}

This research performs accuracy and precision in within-run and between-run. The test was performed using five replicates on each of four concentrations which contain both cyclophosphamide and 4-OHCP, such as LLOQ (50 and 10 $\mathrm{ng} / \mathrm{ml}$ ); QCL (200 and $40 \mathrm{ng} / \mathrm{ml}$ ), QCM (15000 and $500 \mathrm{ng} / \mathrm{ml}$ ) and QCH $(24000$ and $800 \mathrm{ng} / \mathrm{ml})$ for each time of analysis (within-run) and performed as many as three times the analysis of at least 2 different d (between-run). Accuracy is a parameter to see the proximity of the measured concentration results in the analysis with the actual concentration and represented by the \%diff (bias) value, whereas the precision is performed to see the proximity between the repetitions of the measurement analytes represented by the $\mathrm{CV}$ value. The method was accurate and precise because all values met the requirements that bias (\%diff) and $\mathrm{CV}$ for $\mathrm{LLOQ}<20 \%$ while for other concentration levels $<15 \%$. The result can be seen in table 2 and 3.

Table 2: Data of within-run accuracy and precision

\begin{tabular}{|c|c|c|c|c|}
\hline Compounds & Actual conc. (ng/ml) & Meas conc (Average $\pm \mathrm{SD} ; \mathrm{ng} / \mathrm{ml}$ ) & $\% \mathrm{CV}$ & \%diff \\
\hline \multirow[t]{4}{*}{$\mathrm{CP}$} & 50.00 & $47.45 \pm 5.25$ & 11.07 & -17.69 to 10.11 \\
\hline & 200.00 & $197.01 \pm 19.31$ & 9.80 & -11.08 to 10.08 \\
\hline & 15000.00 & $13130.11 \pm 183.47$ & 1.40 & -14.42 to -11.29 \\
\hline & 24000.00 & $21056.89 \pm 582.25$ & 2.77 & -14.78 to -8.36 \\
\hline \multirow[t]{4}{*}{ 4-ОНСР } & 10.00 & $8.39 \pm 0.34$ & 4.04 & -19.92 to -11.02 \\
\hline & 40.00 & $34.83 \pm 0.45$ & 1.30 & -13.82 to -11.40 \\
\hline & 500.00 & $442.26 \pm 10.09$ & 2.28 & -14.12 to -8.57 \\
\hline & 800.00 & $709.72 \pm 24.03$ & 3.39 & -13.54 to -6.21 \\
\hline
\end{tabular}

Table 3: Data of between-run accuracy and precision

\begin{tabular}{|c|c|c|c|c|}
\hline Compounds & Actual conc. (ng/ml) & Meas conc (Average $\pm S D, \mathrm{ng} / \mathrm{ml}$ ) & $\% \mathrm{CV}$ & \%diff \\
\hline \multirow[t]{4}{*}{$\mathrm{CP}$} & 50.00 & $47.45 \pm 5.25$ & 11.07 & -17.69 to 19.05 \\
\hline & 200.00 & $197.01 \pm 19.31$ & 9.80 & -11.08 to 14.30 \\
\hline & 15000.00 & $13130.11 \pm 183.47$ & 1.40 & -14.72 to 10.84 \\
\hline & 24000.00 & $21056.89 \pm 582.25$ & 2.77 & -14.78 to -0.48 \\
\hline \multirow[t]{4}{*}{ 4-ОНСР } & 10.00 & $8.39 \pm 0.34$ & 4.04 & -19.92 to 13.17 \\
\hline & 40.00 & $34.83 \pm 0.45$ & 1.30 & -13.82 to -6.98 \\
\hline & 500.00 & $442.26 \pm 10.09$ & 2.28 & -14.12 to 14.18 \\
\hline & 800.00 & $709.72 \pm 24.03$ & 3.39 & -14.25 to -2.18 \\
\hline
\end{tabular}

Besides accuracy and precision, recovery was conducted to know the extraction efficiency. The recovery was calculated by comparing the area of analyte obtained after extraction with the area of standard analyteat the same concentration. Recovery of cyclophosphamide at three levels of concentration QCL, QCM, and QCL was 28.95-34.01\% and 4-OHCP was 25.88-33.84\%.

\section{e. Dilution integrity}

Dilution integrity was performed to determine whether dilutions carried out during the analysis affects accuracy and precision. The test was performed with a concentration above ULOQ or two times the QCH concentrations of both cyclophosphamide and 4-OHCP $48000 \mathrm{ng} / \mathrm{ml}$ and $1600 \mathrm{ng} / \mathrm{ml}$, diluted to half (24000and $800 \mathrm{ng} / \mathrm{ml}$ ) and one quarter (12000and $400 \mathrm{ng} / \mathrm{ml}$ ) using a whole blood. The analysis was conducted in five replicates on each dilution and observed the accuracy and precision parameters. The result showed that until one quarter dilution, the $\mathrm{CV}$ and $\% \operatorname{diff}<15 \%$.

\section{f. Matrix effect}

Matrix effect was conducted because the analysis of cyclophosphamide and 4-OHCP was using mass spectrometry. The matrix effect describes the presence of other compounds outside the analytes and internal standard in the ionization of the analytes and the internal standard in the ionization process. This effect was represented by the matrix factor by calculating the percentage between the area of analytes added after the blank extraction process with the standard solution area. The result can be seen in table 4 .

Table 4: Data of matrix effect of CP and 4-OHCP in DBS

\begin{tabular}{llllll}
\hline Compounds & $\begin{array}{l}\text { Actual Conc } \\
(\mathbf{n g} / \mathbf{m l})\end{array}$ & \multicolumn{2}{l}{ Matrix factor } & \multicolumn{2}{l}{ Internal standard normalized matrix factor } \\
\cline { 3 - 6 } & & Matrix factor & \%CV & Matrix factor & \%CV \\
\cline { 2 - 6 } & & (Average \pm SD; $\%)$ & & (Average \pm SD; \%) & 6.43 \\
\hline $\mathrm{CP}$ & 50.00 & $87.27 \pm 2.02$ & 2.32 & $0.97 \pm 0.06$ & 8.84 \\
& 24000.00 & $80.45 \pm 5.56$ & 6.91 & $0.89 \pm 0.08$ & 10.10 \\
& 10.00 & $77.74 \pm 5.70$ & 7.33 & $0.86 \pm 0.09$ & 8.84 \\
\hline
\end{tabular}




\section{g. Stability}

The stability test was performed to ensure that the storage condition and sample preparation not affecting the concentration of the analytes. The stability test was performed using QCL and QCH samples of each of the three replicates. For short-term stability tests, samples were stored at room temperature for $24 \mathrm{~h}$. The results showed that both cyclophosphamide and 4-OHCP was stable in DBS for at least $24 \mathrm{~h}$ at room temperature. The long-term stability tests also performed in a freezer temperature of $-80^{\circ} \mathrm{C}$ in the periods of 0 , $7,14 \mathrm{~d}$ and post preparation stability (autosampler). The stability study results showed that cyclophosphamide was stable for at least $14 \mathrm{~d}, 4-\mathrm{OHCP}$ for at least $7 \mathrm{~d}$ in DBS at- $80^{\circ} \mathrm{C}$ and was stable for at least $24 \mathrm{~h}$ in the autosampler. The stock solution of cyclophosphamide, 4-OHCP, and HMO was stable for at least $14 \mathrm{~d}$ in the suitable storage condition.

Table 5: Data of stability test result of CP and 4-OHCP in DBS

\begin{tabular}{lll}
\hline Stability test & Stable at least & \\
\cline { 2 - 3 } & CP & 40HCP \\
\hline Short-term stability $\left(24 \mathrm{~h}, 25^{\circ} \mathrm{C}\right)$ & $24 \mathrm{~h}$ & $24 \mathrm{~h}$ \\
Long-term stability $\left(\right.$ freezer- $\left.80^{\circ} \mathrm{C}\right)$ & $14 \mathrm{~d}$ & $7 \mathrm{~d}$ \\
Auto sampler $(24 \mathrm{~h})$ & $24 \mathrm{~h}$ & $24 \mathrm{~h}$ \\
\hline
\end{tabular}

\section{Application of the methods}

Cyclophosphamide and 4-OHCP were found in 17 of 17 samples of DBS. The average level of cyclophosphamide $2 \mathrm{~h}$ after administration was $18872.498 \mathrm{ng} / \mathrm{ml}$ with CV $42.91 \%$ and the average level of cyclophosphamide $4 \mathrm{~h}$ after administration was $14152.095 \mathrm{ng} / \mathrm{ml}$ with CV $44.37 \%$. Whereas, the average level of 4-OHCP in 17 cancer patients $2 \mathrm{~h}$ after administration was $123.703 \mathrm{ng} / \mathrm{ml}$ with $\mathrm{CV}$ $41.15 \%$ and an average level of 4-OHCP $4 \mathrm{~h}$ after administration was $65.551 \mathrm{ng} / \mathrm{ml}$ with CV $46.15 \%$. Data can be seen at table 6 .

Table 6: Data and result of analysis of cancer patients

\begin{tabular}{|c|c|c|c|c|c|c|}
\hline Patient & Ages (y) & Chemotherapy & Dose & Hours & $\begin{array}{l}\text { Cyclophosphamide concentration } \\
\text { (ng/ml) }\end{array}$ & $\begin{array}{l}\text { 4-OHCP concentration } \\
(\mathrm{ng} / \mathrm{ml})\end{array}$ \\
\hline \multirow[t]{2}{*}{ SN 01} & 39 & FAC & 761 & $2 \mathrm{~h}$ & 11351.887 & 85.951 \\
\hline & & & & $4 \mathrm{~h}$ & 16068.021 & 82.923 \\
\hline \multirow[t]{2}{*}{ SN 02} & 45 & FAC & 810 & $2 \mathrm{~h}$ & 16428.075 & 75.961 \\
\hline & & & & $4 \mathrm{~h}$ & 17268.697 & 78.280 \\
\hline \multirow[t]{2}{*}{ SN 03} & 51 & FAC & 732 & $2 \mathrm{~h}$ & 13157.874 & 70.874 \\
\hline & & & & $4 \mathrm{~h}$ & 15101.936 & 68.972 \\
\hline \multirow[t]{2}{*}{ SN 04} & 58 & FAC & 780 & $2 \mathrm{~h}$ & 26150.655 & 246.362 \\
\hline & & & & $4 \mathrm{~h}$ & 15993.924 & 151.130 \\
\hline \multirow[t]{2}{*}{ SN 05} & 41 & FAC & 920 & $2 \mathrm{~h}$ & 16463.489 & 132.185 \\
\hline & & & & $4 \mathrm{~h}$ & 12680.858 & 49.545 \\
\hline \multirow[t]{2}{*}{ SN 06} & 53 & $\mathrm{TC}$ & 960 & $2 \mathrm{~h}$ & 21175.842 & 160.130 \\
\hline & & & & $4 \mathrm{~h}$ & 14090.253 & 62.488 \\
\hline \multirow[t]{2}{*}{ SN 07} & 44 & FAC & 930 & $2 \mathrm{~h}$ & 21446.954 & 159.699 \\
\hline & & & & $4 \mathrm{~h}$ & 16175.628 & 51.391 \\
\hline \multirow[t]{2}{*}{ SN 08} & 38 & FAC & 750 & $2 \mathrm{~h}$ & 14220.215 & 89.002 \\
\hline & & & & $4 \mathrm{~h}$ & 7067.737 & 39.078 \\
\hline \multirow[t]{2}{*}{ SN 09} & 52 & FAC & 770 & $2 \mathrm{~h}$ & 31091.169 & 90.261 \\
\hline & & & & $4 \mathrm{~h}$ & 15460.019 & 47.877 \\
\hline \multirow[t]{2}{*}{ SN 10} & 52 & FAC & 710 & $2 \mathrm{~h}$ & 19786.121 & 109.894 \\
\hline & & & & $4 \mathrm{~h}$ & 18235.898 & 78.805 \\
\hline \multirow[t]{2}{*}{ SN 11} & 44 & PTX-C & 1114 & $2 \mathrm{~h}$ & 37024.403 & 134.248 \\
\hline & & & & $4 \mathrm{~h}$ & 28033.338 & 82.774 \\
\hline \multirow[t]{2}{*}{ SN 12} & 51 & PTX-C & 948 & $2 \mathrm{~h}$ & 35869.579 & 207.871 \\
\hline & & & & $4 \mathrm{~h}$ & 24545.752 & 101.210 \\
\hline \multirow[t]{2}{*}{ SN 13} & 43 & FAC & 900 & $2 \mathrm{~h}$ & 11578.801 & 99.831 \\
\hline & & & & $4 \mathrm{~h}$ & 8206.822 & 58.059 \\
\hline \multirow[t]{2}{*}{ SN 14} & 39 & FAC & 760 & $2 \mathrm{~h}$ & 13206.363 & 138.825 \\
\hline & & & & $4 \mathrm{~h}$ & 6045.980 & 35.962 \\
\hline \multirow[t]{2}{*}{ SN 15} & 35 & FAC & 720 & $2 \mathrm{~h}$ & 13102.216 & 82.390 \\
\hline & & & & $4 \mathrm{~h}$ & 10591.826 & 33.155 \\
\hline \multirow{2}{*}{ SN 16} & 47 & FAC & 800 & $2 \mathrm{~h}$ & 12671.848 & 131.148 \\
\hline & & & & $4 \mathrm{~h}$ & 7404.476 & 58.688 \\
\hline \multirow[t]{2}{*}{ SN 17} & 48 & FAC & 700 & $2 \mathrm{~h}$ & 6106.981 & 88.315 \\
\hline & & & & $4 \mathrm{~h}$ & 7614.457 & 34.022 \\
\hline
\end{tabular}

\section{DISCUSSION}

Mass detection was carried out using a positive Electrospray Ionization (ESI). Positive ESI mode is used because analyte can be protonated. Cyclophosphamide produces a parent ion with $\mathrm{m} / \mathrm{z}$ 260.968, molecular formula $\mathrm{C}_{7} \mathrm{H}_{16} \mathrm{Cl}_{2} \mathrm{~N}_{2} \mathrm{O}_{2} \mathrm{P}^{+}$and daughter ion with $\mathrm{m} / \mathrm{z}$ 139.978, molecular formula $\mathrm{C}_{4} \mathrm{H}_{8} \mathrm{Cl}_{2} \mathrm{~N}^{+}$. In addition, the semicarbazone 4-OHCP-d4 derivative produces a parent ion with $\mathrm{m} / \mathrm{z}$ 338.011, molecular formula $\mathrm{C}_{8} \mathrm{H}_{14} \mathrm{D}_{4} \mathrm{Cl}_{2} \mathrm{~N}_{5} \mathrm{O}_{3} \mathrm{P}+$ and daughter ion with m/z 224.979, molecular formula $\mathrm{C}_{4} \mathrm{H}_{6} \mathrm{D}_{4} \mathrm{Cl}_{2} \mathrm{~N}_{2} \mathrm{O}_{2} \mathrm{P}^{+}$. HMP produced parent ion with $\mathrm{m} / \mathrm{z}$ 180.17, molecular formula $\mathrm{C}_{6} \mathrm{H}_{19} \mathrm{~N}_{3} \mathrm{OP}^{+}$and daughter ion with $\mathrm{m} / \mathrm{z} 92.08$, molecular formula $\mathrm{C}_{2} \mathrm{H}_{7} \mathrm{NOP}^{+}$. Acquity UPLC BEH C18 column and Vanguard ${ }^{\mathrm{TM}}$ Acquity $\mathrm{BEH}$ precolom was used for analysis. The mobile phase used was $0.01 \%$ formic acid-methanol (50:50) with isocratic elution for $4 \mathrm{~min}$, a flow rate of $0.3 \mathrm{ml} / \mathrm{min}$, and a column temperature of $30^{\circ} \mathrm{C}$ [5].

The BEH C18 column is nonpolar with the mobile phase of $0.01 \%$ formic acid-methanol (50:50) is polar, so this analysis used reversephase chromatography system. 
UPLC-MS/MS instrument and condition in this study was developed for the first time by Harahap, Samuel, Andalusia, and Syafhan by the year of 2016. In this study, the chromatographic condition was applied to develop a new bio sampling method, called DBS.4-OHCP as cyclophosphamide's metabolite was very unstable against the presence of $\mathrm{O}_{2}$ [14]. Therefore, the derivatization procedure is carried out prior to analysis. Derivatization in this study was carried out using semicarbazide hydrochloride to form semicarbazone derivatives $[5,14]$. The procedure of derivatization was performed before the blood containing the analytes was applied on the DBS paper. The procedure of derivatization was developed first by Mess, Taillon, and Côté by the year of 2012 [15] to derivate racecadotril's metabolite, thiorphan with 2-bromo-3'-metoxyacetophenon because it was unstable of oxidation in biology matrix.

DBS preparation was conducted using protein precipitation. This method was chosen because it cleans the analytes of many impurities in the sample and resulting the highest area of the analyte. The optimization was performed by methanol and acetonitrile as a combination of extracting solution because they are polar so the analytes will be extracted into the solvent. Besides, that solvent also have been used on the extraction of ifosfamid and cyclophosphamide in DBS [16]. The optimum sample preparation were obtained by protein precipitation using $1000 \mu \mathrm{l}$ methanolacetonitrile $=2: 1 \mathrm{v} / \mathrm{v}$. The mixture was vortex mixed for $4 \mathrm{~min}$ sonication for $15 \mathrm{~min}$, and centrifugation was performed for $10 \mathrm{~min}$ at $11752.416 \mathrm{~g}$. The supernatants were evaporated and the residue was reconstituted with $100 \mu \mathrm{l}$ of the mobile phase, vortex mixed for $20 \mathrm{~s}$, and centrifuged for $5 \mathrm{~min}$ at $1147.068 \mathrm{~g}$. Afterward, $10 \mu \mathrm{l}$ of aliquot was injected into the chromatography system. The optimization results were selected based on the area of analytes and the internal standard also chromatogram form of each compound.
After acquiring the optimum condition, the analysis method validation was conducted. Based on all value results of validation that met the requirements of Guideline on Bioanalytical Method Validation [12], it can be concluded that the developed method was valid. This research showed LLOQ was $50 \mathrm{ng} / \mathrm{ml}$ for cyclophosphamide and $10 \mathrm{ng} / \mathrm{ml}$ for 4-OHCP. This value fulfilled the European Medicines Agency requirement that was $5 \%$ of $\mathrm{C}_{\max }$. Therefore this new method of bio samping using DBS can be applied in pharmacokinetic studies or bioequivalence studies.

The average levels of cyclophosphamide and 4-OHCP at the $2^{\text {nd }} \mathrm{h}$ was higher than the $4^{\text {th }} \mathrm{h}$. This is in accordance with previous research that at the $2 \mathrm{~h}$ after administration is $\mathrm{C}_{\max }$ time and $4 \mathrm{~h}$ after administration is an elimination time of both compounds [16, 17]. Drug and their metabolites level in each patient can be different. This can be due to the expression level of the CYP enzyme, especially CYB2B6 in the liver, and also the individual capacity to the enzyme. In addition, the level of expression and activity of ALDH isoenzymes can also vary between individuals. Beside polymorphism factors, other factors such as disease status, weight, age, food, dose, stress, dysfunction of other organs such as the liver and kidneys, etc can also affect both compouds level. Graphic of both compounds level can be seen at fig. 3 .

From the results,method that had been developed before could be applied on the analysis of cyclophosphamide and 4-OHCPfor the therapeutic drug monitoring. Cyclophosphamide metabolite, 4OHCP, will be converted to phosphoramide mustard which can alkylate DNA so it can provide a cytotoxic effect on cancer cells.

In this research there were 17 subjects from Dharmais Cancer Hospital to verify the applicability of this method. In order to establish a reliable pharmacokinetics data, more samples are needed to be taken from a bigger pool of subject.

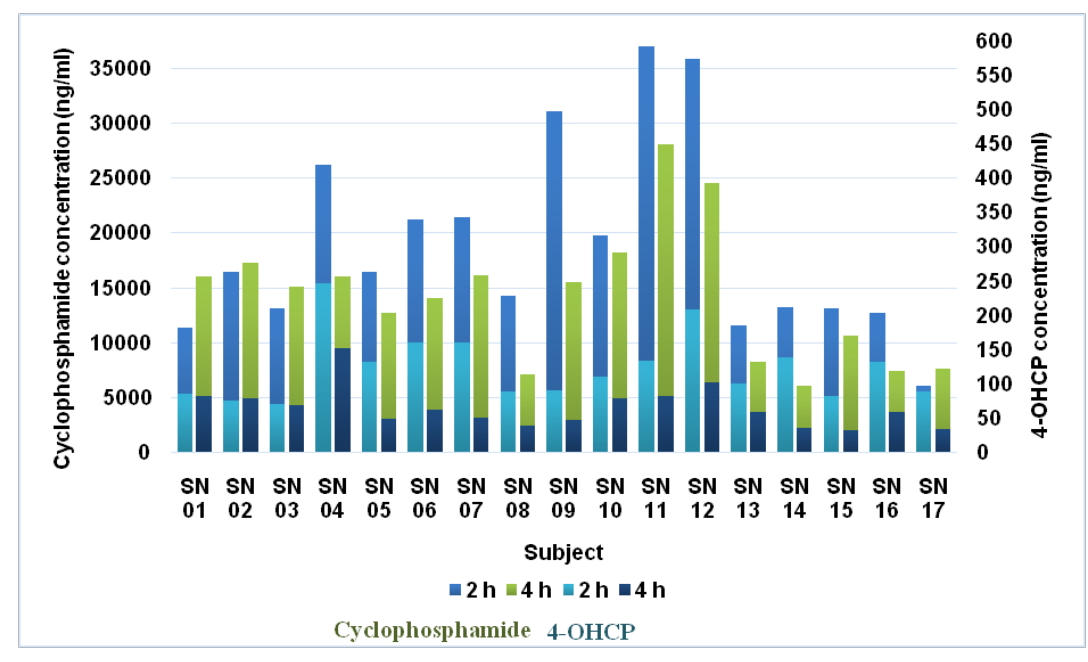

Fig. 3: Bar chart of cyclophosphamide and 4-OHC plevel

\section{CONCLUSION}

In conclusion, this method for quantifying cyclophosphamide and 4OHCP in DBS was successfully developed, validated, and can be applied on breast cancer patients for therapeutic drug monitoring. The LLOQ obtained in this study was $50 \mathrm{ng} / \mathrm{ml}$ for cyclophosphamide and $10 \mathrm{ng} / \mathrm{ml}$ for 4-OHCP. This method is potential to be used on bigger scale of samples.

\section{FUNDING}

Nil

\section{AUTHORS CONTRIBUTIONS}

All authors have contributed equally.

\section{CONFLICT OF INTERESTS}

Declared none

\section{REFERENCES}

1. LaPlant K, Louzon P. Anticancer drug. In: K Whalen, R Finkel, T Panavelil. editors. Lippincott Ilustrated Reviews: Pharmacology. 6th ed. China: Wolters Kluwer; 2015. p. 587617.

2. Chabner BA. Cytotoxic agent. In: L Brunton, B Knollmann, B Chabner. editors. Goodman and gilman's the pharmacological basis of therapeutics. 12th ed. New York: McGraw Hill; 2011. p. 1677-730.

3. Veal GJ, Cole M, Chinnaswamy G, Sludden J, Jamieson D, Errington J, et al. Cyclophosphamide pharmacokinetics and pharmacogenetics in children with B-cell non-hodgkin's lymphoma. Eur J Cancer 2016;55:56-64.

4. Kalhorn TF, Howald WN, Cole S, Phillips B, Wang J, Slattery JT, et al. Rapid quantitation of cyclophosphamide metabolites in plasma by liquid chromatography-mass spectrometry. J Chromatogr B 2006;835:105-13. 
5. Harahap Y, Samuel C, Andalusia R, Syafhan NF. Analysis of 4hydroxycyclophosphamide in cancer patients plasma fortherapeutic drug monitoring of cyclophosphamide. Int J Pharm Pharm Sci 2016;8:194-200.

6. Ekhart C, Gebretensae A, Rosing H, Rodenhuis S, Beijnen JH, Huitema ADR. Simultaneous quantification of cyclophosphamide and its active metabolite 4hydroxycyclophosphamide in human plasma by highperformance liquid chromatography coupled with electrospray ionization tandem mass spectrometry (LC-SM/SM). J Chromatogr B 2007;854:345-9.

7. Sadagopan N, Cohen L, Roberts B, Collard W, Omer C. Liquid chromatography-tandem mass spectrometric quantitation of cyclophosphamide and its hydroxy metabolite in plasma and tissue for determination of tissue distribution. J Chromatogr B 2001;759:277-84.

8. Hussain S, Shaikh T. Ultra high performance liquid chromatography (UPLC): a new trend in analysis. World J Pharm Res 2016;5:387-94.

9. Bai F, Fraga CH, Tagen M, Schaiquevich P, Hagedorn N, Stewart CF. Simulaneous Determination of cyclophosphamide and carboxyethylphosphoramide mustard in human plasma using online extraction and electrospray tandem mass spectrometry (HTLC-ESI-MS/MS). J Chromatogr B 2009;877:1709-15.

10. Baumann F, Lorenz C, Jaehde U, Preiss R. Determination of cyclophosphamide and its metabolites in human plasma by high-performance liquid chromatography-mass spectrometry. J Chromatogr B 1999;729:297-305.
11. Ministry of Health Indonesia. Infodatin: Pusat Data danInformasi Kementerian Kesehatan Republik Indonesia Jakarta; 2015. p. 3.

12. European Medicines Agency. Guideline on Bioanalytical Method Validation, Sciences Medicines Health. London: European Medicines Agency; 2011.

13. Almeida AM, Castel Branco M, Falcao A. Linear regression for calibration lines revisited: weighting schemes for bioanalytical methods. J Chromatogr B 2002;774:215-22.

14. Moldoveanu S, David V. The role of derivatization in chromatography. Modern Sample Preparation for Chromatography; 2015. p. 307-31.

15. Mess J, Taillon M, Cote C. Dried blood spot on-card derivatization: an alternative form of sample handling to overcome the instability of thiorphan in biological matrix. Biomed Chromatogr 2012;26:1617-24.

16. Torres LM, Espinova LR, Pacheco JLC, Navas CF, Demetrio JA, Medina RA, et al. A new method to quantify ifosfamide blood levels using dried blood spots and UPLC-MS/MS in paediatric patients with embryonic solid tumours. Plos One 2015;10:1-13.

17. Joy MS, La M, Wang J, Bridges AS, Hu Y, Hogan SL, et al. Cyclophosphamide and 4-hydroxycyclophosphamide pharmacokinetics in patients with glomerulonephritis secondary to lupus and small vessel vasculitis. $\mathrm{Br} \mathrm{J}$ Clin Pharmacol 2012;74:445-55.

18. Anderson L, Ludeman S, Colvin 0, Grochow L, Strong J. Quantitation of 4-hydroxycyclophosphamide/aldophosphamide in whole blood. J Chromatogr B 1995;667:247-57. 